\title{
KEMAMPUAN MENGUBAH NASKAH PERCAKAPAN DRAMA KE DALAM BENTUK NARASI SISWA KELAS VIII SMP NEGERI I BONTOLEMPANGAN KECAMATAN BONTOLEMPANGAN KABUPATEN GOWA
}

\author{
Rosmida $^{1,}$ Rais Dera P Rawi ${ }^{2}$ \\ ${ }^{1}$ Program Studi Sastra dan Bahasa Universitas Muhammadiyah Makassar \\ ${ }^{2}$ Dosen Program Studi Manajemen Universitas Muhammadiyah Sorong
}

Diterima:4 Oktober 2016. Disetujui:10 November 2016. Dipublikasikan:1 Desember 2016

\begin{abstract}
Abstrak
Penelitian ini bertujuan mendeskripsikan kemampuan siswa kelas VIII SMP Negeri I Bontolempangan Kecamatan Bontolempangan Kabupaten Gowa dalam mengubah naskah percakapan drama ke bentuk prosa narasi. Populasi penelitian ini adalah siswa kelas VIII SMP Negeri I Bontolempangan Kecamatan Bontolempangan Kabupaten Gowa yang berjumlah 114 sedangkan sampel sebanyak 37\% dari populasi atau sebanyak 37 siswa. Untuk mendapatkan data yang akurat, digunakan tes sebagai instrument penelitian. Siswa diberi tugas mengubah naskah percakapan drama ke dalam bentuk prosa narasi. Data yang dikumpulkan dianalisis dengan menggunakan teknik statistik ragam persentase. Hasil penelitian ini menunjukkan kemampuan siswa kelas VIII SMP Negeri I Bontolempangan Kecamatan Bontolempangan Kabupaten Gowa secara umum dapat disimpulkan belum memadai, karena jumlah siswa jumlah siswa yang memperoleh nilai di atas 6,5 hanya sebanyak 21 siswa atau sebesar 56,75\%, hasil ini belum mencapai prinsip belajar tuntas yang menyatakan bahwa ketaatan belajar dikatakan tercapai bila jumlah siswa mencapai $85 \%$ dari jumlah siswa yang mendapat nilai minimal 6,5. Belum maksimalnya kemampuan siswa kelas VIII SMP Negeri I Bontolempangan Kecamatan Bontolempangan Kabupaten Gowa dalam mengubah naskah percakapan drama ke bentuk prosa narasi disebabkan masih kurangnya penguasaan siswa terhadap karya sastra khususnya prosa, dan juga proses belajar mengajar di sekolah tersebut kurang maksimal.

Kata kunci: Kemampuan Mengubah Naskah, Percakapan Drama, Bentuk Narasi
\end{abstract}

\section{PENDAHULUAN}

Komponen keterampilan berbahasa

yang perlu diperhatikan dalam membimbing, mengarahkan dan mengembangkan siswa kearah kemampuan berbahasa secara kreatif, yaitu kemampuan menyimak (listening skills), kemampuan berbicara ( speaking skills), kemampuan membaca (reading skills), dan kemampuan menulis (writing skills) (Tarigan, 1985). Dari keempat komponen keterampilan tersebut, keterampilan yang satu dengan keterampilan yang lainnya saling berkaitan melalui urutan yang teratur.

Secara umum keterampilan menyimak dan berbicara sudah dimulai pada saat anak masih usia prasekolah.
Keterampilan membaca dan menulis diperoleh setelah anak memasuki lembaga pendidikan formal. Dalam kehidupan modern seperti sekarang ini, keterampilan menulis sangat dibutuhkan. Kiranya tidak berlebihan bila dikatakan bahwa keterampilan menulis merupakan cirri dari orang atau bangsa yang terpelajar. Sehubungan dengan hal ini ada seorang penulis yang menyatakan bahwa menulis digunakan oleh seorang terpelajar untuk mencatat, meyakinkan, melaporkan serta mempengaruhi orang lain dan maksud dari tujuan seperti itu hanya dapat dicapai oleh orang-orang yang dapat menyusun buah pikiran dan mengutarakannya dengan jelas. Kejelasan ini tergantung pada

1 Kemampuan Mengubah Naskah Percakapan Drama... 
pikiran, organisasi, pemakaian kata-kata dan struktur kalimat (Tarigan, 1985).

Menulis merupakan suatu keterampilan berbahasa yang dipergunakan untuk berkomunikasi secara tidak langsung atau tidak secara tatap mukadengan orang lain. Menulis juga merupakan suatu kegiatan yang produktif dan ekspresif. Keterampilan menulis tidak akan datang secara otomatis, tetapi harus melalui latihan-latihan dan praktek yang sering kali dan secara teratur, maka tidak heran jika ada yang menjadikan kegiatan menulis sebagai salah satu sumber mata pencaharian tetap, bahkan tidak jarang seseorang menjadi terkenal hanya karena hasil dari kegiatan menulis.

Salah satu hasil kegiatan menulis diantaranya adalah karya sastra. Karya sastra yang dapat ditemukan dalam bentuk tulisan antara lain adalah: puisi, cerpen ataupun naskah drama. Naskah drama merupakan hasil karya tulis genre sastra imajinatif yang mengungkapkan cerita Penelitian yang relevan dengan judul yang diangkat oleh penulis pernah dilakukan oleh:

1. Supratia pada tahun 1999 , dengan judul penelitian "Tingkat Kemampuan Siswa Kelas I SMP Negeri 15 Makassar dalam Mengubah Naskah Percakapan Drama ke Bentuk Prosa". Hasil yang diperoleh dari penelitian ini yaitu masih sangat kurang (belum memadai).

2. Adrian pada tahun 2007, dengan judul penelitian "Kemampuan siswa kelas VIII SMP Negeri I Pamboang dalam Mengubah

\section{Metode Penelitian}

\section{Variabel dan Desain Penelitian}

\section{Fokus Penelitian}

Dalam penelitian ini hanya akan diamati satu variabel (variabel tunggal), yaitu kemampuan siswa kelas VIII SMP Negeri I Bontolempangan Kecamatan Bontolempangan Kabupaten Gowa dalam mengubah naskah percakapan drama ke bentuk prosa narasi. melalui dialog para tokohnya. Naskah drama sebagai karya sastra seharusnya hanya bersifat sementara, sebab naskah drama hanya ditulis sebagai dasar untuk dipentaskan, tetapi naskah drama selalu digolongkan sebagai karya sastra.

Di antara bentuk karya sastra hasil kegiatan menulis seperti yang telah diuraikan di atas, ada yang dapat diubah dari bentuk yang satu ke bentuk yang lain. Naskah drama misalnya dapat diubah ke bentuk prosa atau sebaliknya dari bentuk prosa ke dalam bentuk naskah drama. Pada penelitian ini yang menjadi fokus pembahasan adalah pengubahan naskah drama ke dalam bentuk prosa. Namun demikian, pengubahan dari suatu bentuk sastra ke bentuk sastra lainnya tidak begitu mudah untuk dilakukan. Seperti dikemukakan sebelumnya, untuk melakukan hal tersebut diperlukan ketekunan dan latihan secara terus menerus dan teratur.

Naskah Percakapan Drama ke Bentuk Prosa Narasi". Hasil yang diperoleh pada penelitian ini adalah masih sangat kurang (belum memadai).

3. Mutmainna pada tahun 2008, dengan judul penelitian "Kemampuan Siswa Kelas XI SMA Mauhammadiyah Kalosi Kecamatan Alla Kabupaten Enrekang Mengubah Naskah Cerpen Ke dalam Bentuk Naskah Drama". Seperti pada penelitian yang pertama dan ke dua juga masih sangat kurang (belum memadai).

\section{Desain Penelitian}

Penelitian ini merupakan penelitian deskriptif yang bertujuan untuk mendapatkan gambaran tentang tingkat kemampuan siswa kelas VIII SMP Negeri I Bontolempangan Kecamatan Bontolempangan Kabupaten Gowa dalam mengubah naskah percarcakapan ke bentuk prosa narasi. 
Adapun langkah yang dilakukan dalam penelitian ini yaitu siswa dikumpulkan dalam satu ruangan kemudian diberi naskah percakapan drama untuk diubah ke dalam bentuk karangan prosa narasi. Untuk memperoleh data yang maksimal dan lebih efektif, maka dalam penelitian ini ditentukan variabel yang akan diteliti kemudian dirumuskan masalah yang akan menjadi topik

\section{Populasi dan Sampel}

\section{Populasi}

Populasi dalam penelitian ini adalah seluruh siswa kelas VIII SMP Negeri I Bontolempangan Keacamatan Bontolempangan Kabupaten Gowa tahun pelajaran 2009/2010. Dari hasil observasi yang dilakukan pada sekolah yang menjadi lokasi penelitian, diketahui bahwa jumlah keseluruhan siswa kelas VIII SMP Negeri I Bontolempangan Kecamatan

Tabel 1. Penyebaran Siswa Kelas VIII SMP Negeri I Bontolempangan Kecamatan Bontolempangan Kabupaten Gowa sebagai Populasi Penelitian.

\begin{tabular}{ccccc}
\hline \multirow{2}{*}{ No. } & Kelas & \multicolumn{2}{c}{ Jumlah siswa } & Jumlah \\
& & Laki-laki & Perempuan & \\
\hline 1 & VIIIa & 15 & 22 & 37 \\
2 & VIIIb & 15 & 23 & 38 \\
3 & VIIIc & 16 & 23 & 39 \\
\hline \multicolumn{5}{r}{} \\
\hline
\end{tabular}

Sumber Data: Kantor tata usaha SMP Negeri I Bontolempangan Kecamatan Bontolempangan Kabupaten Gowa.

\section{Sampel}

Jumlah populasinya lebih dari 100 orang dan bersifat homogen, artinya siswa kelas VIII pada SMP Negeri I Bontolempangan Kecamatan Bontolempangan Kabupaten Gowa tidak dikelompokkan tingkat prestasi belajar yang diperoleh pada semester sebelumnya, maka pengambilan sampel dilakukan secara acak (random sampling). Teknik pengambilan sampel dengan menggunakan teknik ini dimaksudkan agar diperoleh sampel yang bersifat mewakili semua populasi atau refresentatif. Cara pengambilan sampel secara acak dilakukan dengan cara me-Lot ketiga kelas yang menjadi populasi, kemudian kelas yang permasalahan. Langkah selanjutnya, menyelidiki variabel dan memberikan definisi operasional variabel. Pada penelitian tersebut dilakukan pembahasan sesuai dengan variabel yang diteliti dengan batasan-batasan rumusan masalah yang ada. Dengan demikian, laporan hasil penelitian ini betul-betul dapat menjawab permasalahan yang ada.

Bontolempangan Kabupaten Gowa adalah 114 siswa yang tersebar pada tiga kelas parallel, yaitu kelas VIIIa, kelas VIIIb, kelas VIIIc.

Untuk lebih jelasnya jumlah dan penyebaran siswa kelas VIII SMP Negeri I Bontolempangan Kecamatan Bontolempangan Kabupaten Gowa sebagai populasi penelitian berdasarkan kelas ditunjukkan pada tabel 1 berikut ini: 
Berdasarkan pendapat tersebut di atas dan jumlah populasi yang ada maka diambil sampel sebanyak 37 orang siswa Teknik Pengumpulan Data

Untuk mendapatkan data yang diperlukan dalam penelitian ini maka digunakan dua teknik pengumpulan data, adapun teknik pengumpulan data sebagai berikut:

\section{Dokumentasi}

Metode ini digunakan untuk mendapatkan data yang berhubungan dengan penelitian ini, yaitu data tertulis tentang jumlah, karakteristik, dan penyebaran siswa kelas VIII SMP Neger I Bontolempangan Kecamatan Bontolempangan Kabupaten Gowa sebagai populasi penelitian. Untuk maksud tersebut, data tentang populasi penelitian diperoleh pada kantor tata usaha SMP Negeri I Bontolempangan Kecamatan Bontolempangan Kabupaten Gowa.

2. Bentuk tes

Unuk mendapat data yang akan menggambarkan tentang tingkat kemampuan siswa kelas VIII SMP Negeri 1 Bontolempangan Kecamatan Bontolempangan Kabupaten Gowa maka digunakan bentuk tes tertulis, yakni tes mengubah naskah percakapan drama ke bentuk prosa narasi sebagai sumber data primer. Dalam pelaksanaan penelitian ini dilakukan beberapa tahap pelaksanaan.

a. Tahap persiapan

Pada tahap ini, siswa yang terpilih sebagai sampel penelitian dikumpulkan pada suatu ruangan

\section{Teknik Analisis Data}

Data yang diperoleh dalam penelitian ini selanjutnya dianalisis dengan menggunakan teknik analisis deskriptif. Teknik analisis deskriptif ini digunakan untuk mendeskripsikan karakteristik variabel penelitian dalam bentuk nilai tertinggi, nilai terendah, rata - rata, modus dan persentase.

Pedoman yang digunakan untuk mengetahui tingkat kemampuan siswa kelas VIII SMP Negeri I Bontolempangan dari seluruh jumlah siswa kelas VIII yang ada.

tertentu. Selanjutnya, diberi pengarahan tentang maksud dan tujuan serta teknik pelaksanaan tes.

b. Tahap pelaksanaan

Pada tahap ini, kepada siswa yang terpilih sebagai sampel penelitian, diberikan naskah percakapan drama untuk diubah menjadi prosa narasi. Naskah percakapan drama yang digunakan dalam penelitia ini berjudul " Tumbang " yang dikutip dari buku teks Kompeten Berbahasa Indonesia.

c. Tahap evaluasi

$$
\text { Pada tahap ini, dilakukan }
$$
pemeriksaan terhadap hasil tes kemampuan mengubah naskah percakapan drama ke bentuk prosa narasi yang telah dilakukan siswa. Untuk menentukan besarnya nilai yang diperoleh siswa, maka digunakan beberapa kriteria tertentu. Krteria - kriteria yang dimaksud adalah sebagai berikut:

1. Kesesuaian tema antara dialog drama percakapan drama dengan bentuk prosa ( bobot 25 ).

2. Isi prosa narasi ( bobot 20 ).

3. Penggunaan ejaan yang tepat (bobot 15 ).

4. Penggunaan bahasa yang sesuai dengan kaidah ( bobot 10 ).

5. Kepaduan antara paragraf yang satu dengan paragraf yang lain (bobot 10 ).

6. Pesan yang ingin disampaikan ( bobot 20 )

Kecamatan Bontolempangan Kabupaten Gowa mengubah naskah percakapan drama ke bentuk prosa narasi mengacu pada rentang yang digunakan di SMP, yaitu $0-10$.

Interval nilai dan kategori yang digunakan untuk menggambarkan tingkat kemampuan siswa kelas VIII SMP Negeri 1 Bontolempangan Kecamatan Bontolempangan Kabupaten Gowa dalam mengubah naskah percakapan drama ke bentuk prosa narasi adalah sebagai berikut: 


\begin{tabular}{cc}
\hline Interval Nilai & Kategori \\
\hline $9,5-10,0$ & Sangat tinggi \\
$7,5-9,4$ & Tinggi \\
$5,5-7,4$ & Sedang \\
$3,5-5,4$ & Rendah \\
$1,5-3,4$ & Sangat rendah \\
\hline
\end{tabular}

Tolok ukur kemampuan siswa ditetapkan bahwa jika jumlah siswa mencapai $85 \%$ yang mendapat nilai $6,5 \mathrm{ke}$ atas, dianggap mampu dan jika jumlah

\section{Hasil Penyajian Analisis Data}

Sesuai dengan jenis penelitian yang dilakukan, hasil penelitian ini adalah hasil kuantitatif. Hasil kuantitatif yang dimaksud dalam penelitian ini adalah hasil yang dinyatakan dalam bentuk angka yang mengukur kemampuan siswa kelas VIII SMP Negeri 1 Bontolempangan Kecamatan Bontolempangan Kabupaten Gowa dalam mengubah naskah percakapan drama ke bentuk prosa narasi.

Penyajian hasil analisis data dilakukan sesuai dengan teknik analisis data yang telah diuraikan di bab

Tabel 2. Rangkuman Distribusi Nilai yang Menggambarkan tingkat Kemampuan Siswa Kelas VIII SMP Negeri I Bontolempangan Kecamatan Bontolempangan Kabupaten Gowa Mengubah Naskah Percakapan Drama ke bentuk Prosa Narasi.

\begin{tabular}{clc}
\hline No. & statistik & Nilai statistik \\
\hline 1. & Jumlah sampel & 37 \\
2. & Nilai tertinggi & 8,5 \\
3. & Nilai terendah & 5,0 \\
4. & Nilai rata-rata & 6,5 \\
5. & Modus & 6,0 \\
\hline
\end{tabular}

Sumber Data: Data Primer Penelitian (2010)

Data pada tabel 2 terlihat bahwa dari 37 siswa kelas VIII SMP Negeri 1 Bontolempangan Kecamatan Bontolempangan Kabupaten Gowa yang menjadi responden penelitian yang menunjukkan tingkat kemampuan mengubah naskah percakapan dama siswa kurang dari $85 \%$ yang mendapat nilai 6,5 dianggap tidak mampu.( Depdikbud, 1994: 39).

sebelumnya. Untuk kepentingan standarisasi hasil pengukuran (skor) dilakukan transformasi dari skor di dalam nilai berskala 1-10 dan menetapkan tolok ukur kemampuan siswa.

Berdasarkan hasil analisis deskriptif, diperoleh rangkuman karakteristik distribusi tingkat kemampuan sampel mengubah naskah percakapan drama ke bentuk prosa narasi.

Untuk lebih jelasnya, rangkuman karakteristik distribusi nilai tersebut ditunjukkan pada tabel 2 berikut ini. 
Negeri I Bonolempangan

Kecamatan Bontolempangan

Kabupaten Gowa adalah 8,5.

2. Nilai terendah yang diperoleh melalui tes kemampuan mengubah bentuk percakapan drama kedalam bentuk prosa narasi siswa kelas VIII SMP Negeri I Bonolempangan Kecamatan Bontolempangan Kabupaten Gowa adalah 5,0

3. Nilai rata-rata yang diperoleh siswa kelas VIII SMP Negeri 1 Bonto Lempangan Kecamatan Bontolempangan Kabupaten Gowa adalah 6,5

Tabel 3 Distribusi Frekuensi, Persentase dan Kategori Tingkat Kemampuan Siswa Kelas VIII SMP Negeri 1 Bontolempangan kecamatan Bontolempangan Kabupaten Gowa mengubah naskah Percakapan Drama ke Bentuk Prosa Narasi

\begin{tabular}{ccccc}
\hline No & Interval nilai & frekuensi & persentase & kategori \\
\hline 1. & $9,5-10,0$ & 0 & 0,0 & Sangat tinggi \\
2. & $7,5-9,4$ & 11 & 29,7 & Tinggi \\
3. & $5,5-7,4$ & 24 & 64,8 & Sedang \\
4. & $3,5-5,4$ & 2 & 5,4 & Rendah \\
5. & $1,5-3,4$ & 0 & 0,0 & Sangat rendah \\
\hline
\end{tabular}

Sumber Data: Data Primer Penelitian (2010)

Berdasarkan hasil analisis deskriptif pada tabel 3 menunjukkan bahwa dari 37 siswa orang siswa kelas VIII SMP Negeri I Bontolempangan Kecamatan Bontolempangan Kabupaten Gowa yang menjadi responden, kategori tingkat kemampuan mengubah naskah percakapan drama ke bentuk prosa narasi dapat diuraikan sebagai berikut:

1. Tidak ada siswa kelas VIII SMP Negeri 1 Bontolempangan Kecamatan Bontolempangan Kabupaten Gowa yang memiliki tingkat kemampuan mengubah naskah percakapan drama ke bentuk prosa narasi yang dikategorikan sangat tinggi.

2. Terdapat 11 atau sekitar $29,72 \%$ siswa kelas VIII SMP Negeri 1 Bontolempangan yang memiliki kemampuan mengubah naskah
4. Nilai modus yang diperoleh siswa kelas VIII SMP Negeri 1 Bontolempangan Kecamatan Bontolempangan Kabupaten Gowa adalah 6,0 Selanjutnya, jika keseluruhan nilai yang diperoleh responden dikelompokkan dalam lima kategori, maka distribusi frekuensi, persentasi dan kategori tingkat kemampuan siswa Kelas VIII SMP Negeri 1 Bontolempanganan Kecamatan Bontolempangan Kabupaten Gowa mengubah naskah percakapan drama ke bentuk prosa narasi ditunjukkan pada tabel 3 berikut ini: 
5. Tidak ada siswa kelas VIII SMP Negeri 1 Bontolempangan Kecamatan Bontolempangan Kabupaten Gowa yang memiliki tingkat kemampuan mengubah naskaha percakapan drama ke dalam bentuk prosa narasi yang dikategorikan sangat rendah.

Untuk lebih jelasnya frekuensi dan distribusi tingkat kemampuan siswa kelas VIII SMP Negeri 1 Bontolempangan Kecamatan Bontolempangan Kabupaten Gowa mengubah percakapan naskah drama ke bentuk prosa narasi dapat digambarkan dalam bentuk diagram batang sebagai berikut:

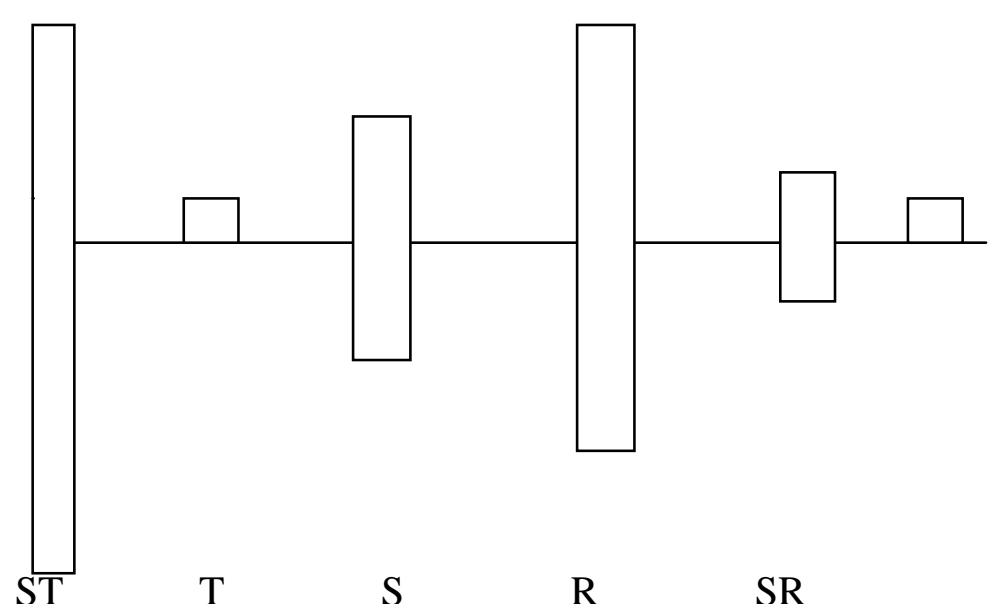

Keterangan:

$$
\begin{aligned}
& \mathrm{ST}=\text { Sangat Tinggi } \\
& \mathrm{T}=\text { Tinggi }
\end{aligned}
$$

\section{Pembahasan}

Berdasarkan hasil analisis data yang telah dilakukan seperti yang telah diuraikan pada bagian sebelumnya, maka hasil penelitian menunjukkan bahwa secara umum tingkat kemampuan siswa kelas VIII SMP Negeri 1 Bontolempangan Kecamatan Bontolempangan Kabupaten Bontolempangan mengubah naskah percakapan drama ke bentuk prosa narasi dikategorikan tinggi. Hasil temuan penelitian didukung oleh beberapa fakta dan data seperti yang terlihat pada tabel 4.3 yakni:

1. Nilai rata-rata yang diperoleh siswa adalah 6,5 dari 11 tertinggi yang bisa dicapai. Artinya nilai rata-rata tingkat kemampuan siswa kelas VIII SMP Negeri 1 Bontolempangan Kecamatan Bontolempangan Kabupaten Gowa mengubah naskah percakapan drama ke bentuk prosa narasi adalah 6,5. Jika nilai rata-rata

$$
\begin{aligned}
& \mathrm{S}=\text { Sedang } \\
& \mathrm{R}=\text { Rendah } \\
& \mathrm{SR}=\text { Sangat Rendah }
\end{aligned}
$$

ini di konversi masukkan ke dalam tabel distribusi frekuensi dan pengategorian, maka tingkat kemampuan siswa kelas VIII SMP Negeri 1 Bontolempangan mengubah naskah percakapan drama ke bentuk prosa narasi dikategorikan sedang karena berada pada interval nilai 5,5 sampai 7,4 .

2. Nilai modus yang diperoleh siswa adalah 6,0. Jika nilai modus ini di konversi ke dalam tabel distibusi frekuensi dan pengategorian, maka gambaran tingkat kemampuan siswa kelas VIII SMP Negeri 1 Bontolempangan Kecamatan Bontolempangan Kabupaten Gowa mengubah naskah percakapan drama ke bentuk prosa narasi dikategorikan sedang karena pada interval nilai 5,5 sampai 7,4.

3. Besarnya frekuensi serta persentase kelompok siswa yang memiliki 
rentang nilai antara 5,5 sampai 7,4 yang dalam tabel distribusu frekuensi berada pada kategori sedang.

Dengan demikian dapat ditegaskan bahwa tingkat kemampuan siswa kelas VIII SMP Negeri 1 Bontolempangan Kecamatan Bontolempangan Kabupaten Gowa mengubah naskah percakapan drama ke bentuk prosa narasi belum memadai. Kenyataan ini juga didukung oleh fakta yang mengungkapkan bahwa dari 37 siswa kelas VIII SMSP Negeri 1 Bontolempangan Kecamatan Gowa dalam mengubah naskah percakapan drama ke bentuk prosa narasi belum memadai. Kriteria ini didasarkan pada prinip belajar tuntas yang menyatakan KESIMPULAN

Berdasarkan hasil penelitian analisis data dan pembahasan hasil pnelitian yang telah dilakukan sebelumnya, maka temuan pnelitian ini disimpulkan sebagai berikut:

1. Secara umum tingkat tingkat kemampuan siswa kelas VIII SMP Negeri 1 Bontolempangan Kecamatan Bontolempangan Kabupaten Gowa mengubah naskah percakapan drama ke bentuk prosa narasi dikategorikan sedang, hal ini terlihat dari tingginya persentase dan frekuensi siswa $(64,86 \%)$ yang memiliki nilai yang berada pada rentang nilai 5,5 sampai 7,4 .

2. Frekuensi dan persentase siswa kelas VIII SMP Negeri 1 Bontolempangan Kecamatan

\section{DAFTAR PUSTAKA}

Arikunto, S. 1985. Prosedur Penelitian. Jakarta: Bumi Aksara.

Adrian. 2007. Kemampuan Siswa Kelas VIII SMP Negeri I Pamboang dalam Mengubah Naskah Percakapan Drama ke Bentuk Prosa Narasi. Skripsi, tidak diterbitkan. Makassar, FKIP UNISMUH.
Bontolempangan Kabupaten Gowa yang menjadi responden dalam penelitian ini, sebanyak 29,7\% dikategorikan tinggi dan $64,8 \%$ yang memiliki tingkat kemampuan yang dikategorikan sedang.

Berdasarkan hasil penelitian yang telah dilakukan di atas menunjukkan bahwa siswa yang memperoleh nilai $6,5 \mathrm{ke}$ atas sejumlah 21 orang atau 56,75\%, berarti yang memperoleh nilai di bawah 6,5 sejumlah 16 orang atau $43,24 \%$. Hal ini menunjukkan bahwa kemampuan siswa kelas VIII SMP Negeri 1 Bontolempangan Kecamatan Bontolempangan Kabupaten bahwa ketaatan belajar dikatakan tercapai bila sejumlah siswa atau $85 \%$ dari jumlah siswa mencapai nilai 6,5 .

Bontolempangan Kabupaten Gowa yang memiliki tingkat kemampuan mengubah naskah percakapan drama ke bentuk prosa narasi yang dikategorikan tinggi sebanyak $29,72 \%$ atau sekitar 11 orang siswa dan berada pada rentang nilai 7,5 sampai 9,5 .

3. Berdasarkan pada prinsip belajar tuntas yang menyatakan bahwa ketaatan belajar dikatakan tercapai bila sejumlah siswa atau $85 \%$ dari jumlah siswa mencapai nilai 6,5 maka kemampuan siswa kelas VIII SMP Negeri 1 Bontolempangan Kecamatan Bontolempangan Kabupaten Gowa mengubah naskah percakapan drama ke bentuk prosa narasi belum memadai.

Badrun, A. 1983. Pengantar Ilmu Sastra. Surabaya: Usaha Nasional.

Depdikbud. 1994. Departemen Pendidikan dan Kebudayaan. Jakarta.

Depdikbud. 1999. Kamus Besar Bahasa Indonesia. Jakarta: Balai Pustaka.

Depdikbud. 1997. Citra Manusia dalam Drama Modern 1960 - 1980. Jakarta: Pusat Pembinaan dan Pengembangan Bahasa. 
Harjana, A. 1985. Kritik Sastra,Sebuah Pengantar. Jakarta: Gramedia.

Mutmainna, R. 2008. Kemampuan Siswa Kelas XI SMA Muhammadiyah Kalosi Kecamatan Alla Kabupaten Enrekang Mengubah Naskah Cerpen ke dalam Bentuk Naskah Drama. Skrips. tidak diterbitkan. Makassar, FKIP UNISMUH.

Nafiah, A. H. 1981. Anda Ingin Jadi Pengarang. Surabaya: Usaha Nasional.

Nusu, A. R. 1992. Apresiasi Sastra I. Ujung Pandang: FPBS IKIP Ujung Pandang.

Semi, M. A. 1988. Metode Penelitian Sastra. Bandung: Angkasa.

Sumarjo, J. 1884. Memahami kesusastraan. Bandung: Alumni.

Surana. 1995. Materi Pelajaran Bahasa Indonesia. Jakarta: Tiga Serangkai.

Supratia. 1999. Tingkat Kemampuan Siswa Kelas I SMP Negeri 15
Makassar dalam Mengubah Naskah Percakapan Drama ke Bentuk Prosa. Skripsi, tidak diterbitkan. Makassar, FKIP UNISMUH.

Tarigan, H. G. 1985. Menulis sebagai Suatu Keterampilan Berbahasa. Bandung: Angkasa.

— H. G. 1985. Prisip - Prinsip Dasar Sastra. Bandung: Angkasa.

Tjokroatmojo, dkk,. 1985. Pendidikan Seni Drama ( suatu pengantar). Surabaya: Usaha Nasional.

Zulfanhur, Z. F. ; Sayuti, K.; dan Zuniar, Z. A. 1996. Teori Sastra. Jakarta: Departemen Pendidikan dan Kebudayaan. 